\title{
AN ECOLOGICAL PERSPECTIVE IN EVOLUTIONARY THEOLOGY
}

\begin{abstract}
A new paradigm in theology, termed evolutionary theology, supports the understanding of ecology as the proper ordering of the relations between living organisms and their environment. It is argued that evolutionary theology yields a unique conceptual framework in which the human species share a common history with the entire Universe and respecting nature's integrity means securing a common destiny to everything that exists. This is a powerful motivation for adopting a balanced ecological attitude aimed at respecting nature's inherent integrity. Furthermore, proposing theological arguments to substantiate ecological claims will help neutralize the objections that religion as such promotes anti-ecological attitudes. Such objections become more pressing when religion focuses exclusively on the afterlife in the immaterial and eternal world to come, and neglects the well-being of the material and temporal Universe.
\end{abstract}

Keywords: evolution; ecology; harmony; picture of the world; new creation

1. Introductory remarks. 2. The contemporary concern. 3. Methodological issues. 4. A better home beyond Earth? 5. Nature that cooperates. 6. Conclusions.

\section{INTRODUCTORY REMARKS}

The rational exploitation and protection of the natural environment and its resources have become one of the central contemporary issues that arise in the context of the relations of mankind to the totality of reality in which man lives and, most importantly, with which man interacts. It has also received proper attention in the teachings of the Catholic Church as evidenced by the writings of the following popes: John XXIII, ${ }^{1}$ Paul VI, ${ }^{2}$ John Paul II, ${ }^{3}$ Benedict XVI ${ }^{4}$ and Francis

1 John XXIII, Encyclical Pacem in Terris.

2 Paul VI, Apostolic Letter Octogesima Adveniens, Art. 21, AAS 63(1971), 416-417.

3 John Paul II, Catechesis (17 January 2001), Art. 4, Insegnamenti 41(2001)1, 179.

4 Benedict XVI, Address to the Diplomatic Corps Accredited to the Holy See (8 January 2007), AAS 99(2007), 73. 
who authored in 2015 a seminal encyclical on the topic of ecology entitled Laudato si. Equipped with intellect, man possesses the unique ability to discover the laws governing the Universe whereby he or she is able to exercise considerable control over the course of natural events and subject the powers of nature to his/her specific goals. This ability manifested itself from the times of the ancient Greece to the Ionian School of the philosophy of nature when nature was demythologized, that is, its functioning was no longer perceived as dependent on the arbitrary decisions of deities but as resulting from the regularities built into nature's own fabric 5 . In short, this was the birth of science. There is no doubt that science accords with the biblical command to Adam and Eve in the Book of Genesis: "And God blessed them, and God said unto them, Be fruitful, and multiply, and fill the earth, and subdue it: and have dominion over the fish of the sea, and over the fowl of the air, and over every living thing that moves upon the earth". ${ }^{6}$

The aim of this article is to employ the outcomes of evolutionary theology to provide theological support to ecology understood as the proper ordering of the relations between living organisms and their environment. Evolutionary theology is a novel paradigm in theology that assumes the evolutionary dynamic picture of the Universe as its conceptual foundation. The beginnings of evolutionary theology reach back to the works of Teilhard de Chardin ${ }^{7}$ and Karl Rahner. ${ }^{8}$ The major contribution to its establishment and development, however, comes from the works of such renowned contemporary scholars as

5 E.g.: O. Pedersen, The Two Books: Historical Notes on Some Interactions Between Natural Science and Theology, Vatican Observatory Foundation, Vatican City 2007, 4-7; Francis, Encyclical Laudato si', Art. 78.

6 Gen 1:28.

7 T. de Chardin, The Phenomenon of Man, William Collins, London 1959.

8 K. Rahner, Christology Within an Evolutionary World, in: K. Rahner, Theological Investigations V, Helicon Press, Baltimore 1966, 157-192. 
Arthur Peacocke, ${ }^{9}$ John Haught, ${ }^{10}$ Dennis Edwards, ${ }^{11}$ Francisco J. Ayala, ${ }^{12}$ and Michael Heller. ${ }^{13}$ It will be argued that evolutionary theology yields a suitable conceptual environment in which all beings in the Universe (including the human species) are recognized to share a common history and that respecting nature's integrity means securing our common destiny. This yields a powerful motivation for adopting the balanced ecological attitude aimed at respecting nature's inherent integrity. Also, employing theological arguments to substantiate ecological claims will serve the additional purpose of alleviating the objections that religion promotes anti-ecological attitudes. Such objections arise on the grounds that religion focuses exclusively on the afterlife in the immaterial and eternal world to come and neglects the well-being of the material and temporal Universe. For instance, the Australian philosopher John Passmore asserts that the most suitable conceptual framework to foster ecological attitudes is pure naturalism because the belief that the Earth is man's only and final home provides a much stronger ecological motivation. ${ }^{14}$ Ultimately, one can hope that evolutionary theology will assist in bringing Pope Francis' urge for an ecological conversion into a satisfactory fulfillment.

9 E.g.: A. Peacocke, Theology for a Scientific Age, Fortress Press, Minneapolis, 1993.

10 J. Haught, Is Nature Enough?: Meaning and Truth in the Age of Science, Cambridge University Press, Cambridge 2006; J. Haught, God After Darwin: A Theology of Evolution, Westview Press, Boulder 2008; J. Haught, Making Sense of Evolution: Darwin, God and the Drama of Life, Westminster John Knox Press 2010; J. Haught, Resting on the Future: Catholic Theology for an Unfinished Universe, Bloomsbury, New York - London - Oxford - New Delhi - Sydney 2015; J. Haught, The New Cosmic Story: Inside Our Awakening Universe, Yale University Press, New Haven - London 2017.

11 E.g.: D. Edwards, The God of Evolution: A Trinitarian Theology, Paulist Press, New York 1999.

12 F.J. Ayala, Darwin's Gift to Science and Religion, Joseph Henry Press, Washington 2007.

13 E.g.: M. Heller, Sens życia i sens Wszechświata, Tarnów, Biblos 2002, 135-151.

14 J. Passmore, Man's Responsibility for Nature, Scribner, New York 1974, 184. 


\section{THE CONTEMPORARY CONCERN}

The process of subduing the Earth has gained a new momentum with the onset of the contemporary scientific method that dates back to the times of Galileo in the 17th century. In contrast to the pre-scientific era, in which science largely relied on the passive observation of nature, the contemporary method is active in its pursuit as it centers on asking questions to nature in the form of carefully designed experiments. As a result, nature reveals its regularities that find their best expression with the use of the language of mathematics. It remains beyond doubt that the scientific method is aggressive, namely, it allows for the penetration of the most distant areas of reality ranging from the Planck level on the scale of $10^{-34} \mathrm{~m}$ to the cosmic scale of $10^{30} \mathrm{~m}$. Moreover, science has the power to unlock the mysteries of systems of very high complexity such as the human brain. One can get the impression that the humble subduing of nature may easily transform into man's desire to conquer nature and lord over it in an entirely unconstrained manner. Inasmuch as man's power in this regard is significant, scientists of great authority such as Albert Einstein, for instance, have clearly expressed their conviction on the radical disproportion between the limited depth of the scientific grasp and the vast areas of the physical reality yet to be discovered. ${ }^{15}$ Contrary to many scientistic claims, the human mind is nowhere near the total dominion over nature. Therefore, attitudes of humility and respect for nature's integrity should be the norm.

A cursory survey of the contemporary scene, however, leads to the inescapable conclusion that in many areas human intervention on nature has considerably shifted from subduing to exploitation and, to put things bluntly, to the extorsion of nature for the sole purpose of consumption. This, in turn, has effected a marked imbalance in nature that results in pollution, global climate change, destruction of

15 A. Einstein, The World As I See It, Forum and Century 84(1931), 193-194. 
forests, disappearance of species of plants and animals. Pope Francis expresses the following concern: "The continued acceleration of changes affecting humanity and the planet is coupled today with a more intensified pace of life and work which might be called "rapidification «. Although change is part of the working of complex systems, the speed with which human activity has developed contrasts with the naturally slow pace of biological evolution. Moreover, the goals of this rapid and constant change are not necessarily geared to the common good or to integral and sustainable human development. Change is something desirable, yet it becomes a source of anxiety when it causes harm to the world and to the quality of life of much of humanity". ${ }^{16}$

At this point a true paradox emerges: the laws of the Universe have toiled for billions of years to bring about the complexity and diversity of living forms in the Universe crowned at the late stage of its development with the human brain, in which complexity comes to its proper peak. And it is now this very brain or, more precisely, the human mind that is endowed with the capacity to turn against what the entire Universe has brought forth and, ultimately, itself.

The upsetting of the balance of nature strikes most visibly at the heart of the Greek understanding of the Universe as a manifestation of harmony expressed in the proportions that govern the extremely complex relations between organisms living in the Universe and their environment. This is precisely the place where ecology enters the scene with its aim of establishing the nature of these relations and deepening our understanding of why they take up a particular form that optimizes the welfare of all that lives. After all, no living organism can exist without the environment. Consequently, ecology claims the authority to formulate the laws which make the subduing of nature by humans rational. It is the very belief in the existence of this rationality that entitles ecologists to voice their concerns when

16 Francis, Laudato si', op. cit., Art. 18. 
nature's harmony is disrupted and nature is irrationally exploited. Although the preventive aspects of ecology seem to dominate its common understanding in the public discourse, in the strict sense they are derivative of what ecology sets as a standard of the rational measures for handling natural resources.

Inasmuch as one can offer many natural arguments why the harmony of the relations between living organisms and their environments need to be safeguarded, the theological perspective on ecology yields additional reasons for fostering ecological attitudes. Pope Francis affirms this point in the following way: "This responsibility for God's earth means that human beings, endowed with intelligence, must respect the laws of nature and the delicate equilibria existing between the creatures of this world, for "he commanded and they were created; and he established them for ever and ever; he fixed their bounds and he set a law which cannot pass away « (Ps 148:5b-6)". ${ }^{17}$

Theological reasons will obviously count as a legitimate reference point for those who are believers. Theology brings in the additional reason why the environment in which man lives does not constitute his/her exclusive property, with which they can proceed as they please. Both man and the environment are effects of the Divine creative activity and, consequently, they are dependent on the laws inscribed into nature by God. In other words, theology shows why man cannot qualify as nature's sovereign and that human beings are but elements of the overarching Divine plan of creation. ${ }^{18}$ Thus, the theology of creation constitutes the main area of theological inquiry pertinent to the justification of the rationality revealed by ecology.

From the theological point of view creation means the commencement of the existence of the contingent order of being. The question on the origin of the variety of non-living and living forms in the Universe, however, belongs to the domain of science,

17 Francis, Laudato si', op. cit., Art. 68.

18 Ps 24:1, Det 10:14, Lev 25:23. 
which, as it has been explained above, has the capacity to unveil the laws that govern the possible changes of organization and complexity in the physical world. In order to emphasize the Divine causality not only at the moment of creation but also in the maintenance of the totality of things in existence, the term creation continua has been coined out. This expression has acquired its extended meaning in the context of evolutionary theology, in which creation is understood as a continuing process that increases the complexity of the Universe by means of the laws of evolution. Such a process will bring the Universe to its ultimate fulfillment.

\section{METHODOLOGICAL ISSUES}

Before delving into theological arguments for ecological concerns, a brief methodological justification of the claims of evolutionary theology seems fitting. ${ }^{19}$ Most generally, theology aims at the conceptual exposition of the content of revelation. Since it is always man who is the recipient of the Divine revelation, theology is conditioned by the relation between man and God, that is, the encounter of the human mind with the revealed content. ${ }^{20}$ Consequently, purely naturalistic conceptual frameworks must be used in order to provide the proper expression of this content. This entails that an absolutely objective theological cognition is impossible. This idea was boldly articulated by Rahner, who insisted on this issue - relativized transmission and acceptance of the tenets of faith. ${ }^{21}$ Moreover, the theological expression can never escape the significant tension between the finite character of the conceptual basis and the

19 For a broader introduction to the pertinent methodological issues in theology see: W.P. Grygiel, Evolutionary Theology: A New Chapter in the Relations between Theology and Science, Studia Philosophiae Christianae 56(2020)3, 101-123.

20 Vatican II, Dei Verbum, Art. 11, 12.

21 E.g.: K. Rahner, Anthropologie (theologische), in: Lexikon für Theologie und Kirche, ed. J. Höfer, K. Rahner, Freiburg/Br. 1957-67, col. 618-627. 
infinity of God. That is, concepts can never reach the Divine essence in a literal sense, but only by means of analogy (metaphor).

It is now commonly maintained that each theological formulation depends on a picture of the world, that is, a set of beliefs on the structure of the Universe, the nature of man and the nature of human cognition. As a result, religious beliefs engage elements of both religious and non-religious nature and the tools to regulate the non-religious component lie outside of the competence of religion. ${ }^{22}$ This is deeply affected by the changing picture of the world because it depends directly on the scientific knowledge of the structure of the Universe. Since religious beliefs must out of necessity reflect truth or, more precisely, be in its closest possible proximity, the unceasing improvement of the picture of the world that they contain is of prime importance for their credibility. ${ }^{23}$ It was clearly indicated by St. Basil that our increasing knowledge of the Universe results in the constant improvement of the conceptual basis of theology, whereby more fitting analogies can be developed to refract the Divine essence. ${ }^{24}$

The dependence of the theological expression on the picture of the world yields the proper methodological foundation for the paradigm of evolutionary theology. By saying that theology is evolutionary, however, one by no means implies the relativization of the Divine truths. Rather, one merely points to the shift of the conceptual basis of the theological expression from the pre-scientific, static picture of the world to the scientific and dynamic one. ${ }^{25}$ According to the dynamic picture, the currently observed great complexity and diversity of

22 E.g.: M. Heller, Naukowy obraz świata a zadanie teologa, in: Obrazy świata w teologii i w naukach przyrodniczych, ed. M. Heller, S. Budzik, S. Wszołek, Biblos, Tarnów 1996, 13-27; Z. Liana, Teologia a naukowe obrazy świata, in: Wiara i nauka, ed. J. Mączka, Wydawnictwo Uniwersytetu Jagiellońskiego, Kraków 2010, 69-90.

23 St. Augustine, De Genesi ad litteram I, 19-20; PL 34, 260 f.

24 St. Basil, De legendis gentilium libris, PG 31, 565 and 568.

25 E.g.: J. Turek, Filozoficzno-światopoglądowe implikacje dynamicznego obrazu wszechświata, in: Obrazy świata w teologii i w naukach przyrodniczych, op. cit., 125-145. 
living organisms results from the process of their gradual evolution from simpler forms, with natural selection as its main mechanism. ${ }^{26}$

\section{A BETTER HOME BEYOND EARTH?}

The detailed explanation of the 'picture of the world' category will now serve to illustrate the main point of this inquiry, namely, that the dynamic picture of the world allows for a much more powerful articulation of ecological concerns. To this end, one needs to focus in particular on the profound change of the character of the theological account of the relation of man to the Universe, which follows from replacing the static, pre-scientific picture of the world with the dynamic and scientific one. The nature of this change has been thoroughly studied and characterized by John Haught, one of the contemporary leading evolutionary theologians. The outcomes of his penetrating analysis will constitute the basis for showing how evolutionary theology can be usefully employed to articulate a theological support for ecology.

The central theme which permeates most of Haught's theological writings concerns what he terms the metaphysics of the future. His major goal is to give a proper expression to one of the fundamental biblical threads, namely, that of the Divine promise. He maintains that the evolutionary picture of the world, in which the Universe is yet unfinished, is the best conceptual framework for this purpose. There is no doubt that Haught is strongly reliant on Teilhard de Chardin, to whom he makes numerous references. In order to achieve a better comparative effect, however, Haught sets his analysis against two other pictures of the Universe: the archeological and the analogical. He terms the evolutionary picture anticipatory. ${ }^{27}$ Since the archeological picture supports anti-religious attitudes, it remains beyond the scope

26 E.g.: F.J. Ayala, Darwin's Gift to Science and Religion, op. cit.

27 J. Haught, Resting on the Future, op. cit., 58-64. 
of this paper and will no longer be referred to in what follows. It concerns the interplay between the analogical and anticipatory pictures, which allows for a proper articulation of the impact of evolutionary theology on the radical improvement of theological support to ecological attitudes.

'Analogical' refers to the pre-scientific, static picture of the world that still dominates much of contemporary theological thinking. The central characteristic of this picture is that the perfection of the order created derives from its participation in the ultimate perfection of God. ${ }^{28}$ Participation in turn entails analogy. Consequently, nature takes up a hierarchical form in which each level reveals the Divine mystery proportionally to its closeness to what is eternal. Haught rightly notices that this picture can be also referred to as 'sacramental' because it allows for the manifestation of what is sacred. In other words, creation has the capability of making the Divine analogically present whereby nature's beauty and diversity symbolize the Divine. By having a sacramental character, nature acquires a unique value for what it is and that very value becomes a safeguard against the exploitation of nature for the particular goals of man. The ensuing obligation of reverence towards creation provides legitimate justification for ecological concerns. However, Haught argues that the analogical picture may also promote a detachment from the world since it is only in the full communion with the Divine fullness that man finds his or her final goal. Nature is not ultimate and man can easily perceive himself or herself only as a pilgrim through "the valley of tears". The following quote exhaustively captures Haught's major theological point: "Traditional otherworldly Catholicism has

28 St. Thomas Aquinas, Summa Contra Gentiles III, 64, 9: "Res autem participat divinam bonitatem per modum similitudinis, inquantum ipsae sunt bona. Id autem quod est maxime bonum in rebus causatis, est bonum ordinis universi, quod est maxime perfectum, tu philosophus dicit: cui etiam consonat Scriptura divina, Gen. 1., cum dicitur, vidit Deus quae fecerat, et erat valde bona, cum de singulis operibus dixisset simpliciter quod erat bona”. 
often turned the sense of religious homelessness into ecologically problematic cosmic homelessness. It has promoted a spirituality of detachment that works against a sense of being at home in nature... A sense of not belonging to nature undoubtedly promotes ecological indifference. A predilection for cosmic homelessness can twist the ideal religious homelessness into an escapism that makes nature a victim of puritanical, perfectionist spiritual detachment. Earth, in that case, comes as a place to get away from in order to find salvation. The natural world then serves the function of being only a "school in which the soul undergoes a discipline that renders it worthy of inheriting eternal life apart from nature". ${ }^{29}$

To sum up, eschatology becomes dangerously detached from creation. Aware of this evident drawback of the sacramental picture of the world, Haught asks the fundamental question: "How then can we love God without turning our backs on the natural world? And how can we come to cherish the natural world without surrendering our restless longing for transcendence?". 30

\section{NATURE THAT COOPERATES}

As already mentioned, Haught argues that the concerns for the ecological impact of the sacramental picture of the world are greatly alleviated in the context of the anticipatory picture of the world. This picture rests on the assumption that the Universe is yet unfinished and in the constant process of creatio continua driven by the laws of evolution. Most importantly, however, this picture allows one to bring evolution, eschatology and ecology into a common focus from the perspective of the Divine promise, which has been implanted into the Universe at the moment of its original creation. This promise in turn finds is proper expression in the biblical idea of the new creation,

29 J. Haught, Resting on the Future, op. cit., 156.

30 Ibid. 
which, as clearly illustrated by St. Paul, concerns the entirety of creation being brought into its final fulfillment (Rom 8:22). Haught adds: "Any ecological theology failing to root itself in the cosmic eschatological vision, that is, in faith's sense that God's promise covers the whole evolutionary sweep op creation, is incomplete and only tangentially biblical". ${ }^{31}$ What this means is that eschatology brings this evolving cosmos to the ultimate state of the new creation, a process characterized by a marked continuity between the present and the world to come. According to such a reading, there arises a strong obligation to protect the natural world at any moment of the Universe's history because by keeping the integrity and beauty of what evolution has already brought forth, man strengthens his/her own hope for the final renewal of everything that exists.

Interestingly enough, Haught does not argue that protecting the natural world secures the subjective sense of the final fulfillment. Rather, he merely stresses the objective requirement that this very fulfillment will indeed take place. this means that by adopting proper ecological attitudes man takes direct responsibility for the new creation, because neglecting ecology may directly upset the course of evolution. Haught captures this issue in the following passage: "Those who are sensitive thought the element of promise in nature with the mourn the poisoning of land, air, streams, oceans, and that destruction of ecosystems everywhere, not only for the suffering this causes us humans but also because such negligence leads logically to the termination of terrestrial evolution, and surely also to a frustration of God's own creative envisagement of the future. It is not all that the human present but also the cosmic future that is diminished by our ecological devastation". ${ }^{2}$

With this major inference in view, Haught moves on to consider two additional points that expand on the ecological import of

31 J. Haught, God After Darwin, op. cit., 159.

32 Ibid, 168. 
evolutionary theology. ${ }^{33}$ Firstly, since the Universe is unfinished and in the constant process of creation continua, it lacks perfection and, consequently, it does not deserve the attitude of prostration but rather that of veneration and respect. In stating this Haught clearly wishes to eschew the aforementioned claims of the naturalist and anti-religious agendas, which derive their ecological motivations from perceiving nature as man's ultimate fulfillment. In other words, the true motivations for ecological attitudes should not come from treating nature as divine here and now, but from acknowledging nature's path to attaining what Teilhard de Chardin would name the Omega point. Secondly, the unfinished character of the Universe indicates that the Earth may offer limited amounts of natural resources and that rationality has to be observed in the process of taking advantage of its resources. In addition to these two points, Haught seems to draw broader implications by touching upon one of the most central issues in natural theology, namely, that of evil, cruelty and perishability in the Universe. He states that: "living with a sense that nature is promise rather than perfection allows us to tolerate its transiency and its defects, including instances where it seems indifferent to us". ${ }^{34}$

Unfortunately, the scope of this paper does not allow for any further elaboration on this intriguing issue.

\section{CONCLUSIONS}

The overall outcome of the inquiry carried out in this paper does not leave a doubt that by resorting to the conceptual tools of evolutionary theology one obtains much stronger motivations for ecology, as compared to incentives offered by classical theology grounded in the static, pre-scientific picture of the world. The novelty brought out by this promising contemporary paradigm in theology consists in accepting

33 Ibid, 163-166.

34 Ibid, 166. 
that man and the physical Universe are very tightly coupled by sharing a common history, the 'stuff' they are made out of and, ultimately, a destiny. The depth of this coupling is best evidenced in the assertion that the Universe must be both large and old to bring forth an entity of such complexity as a human being. ${ }^{35}$ Since the Earth can no longer be considered as man's cosmic exile and, most importantly, preserving the integrity of what has so far been produced by evolutionary mechanism impacts the paths to the new creation, there arises a profound moral obligation to secure the rational character of the relations of man to nature and its resources. Deepening our understanding of the importance of ecology achieved within evolutionary theology constitutes an important outcome that will certainly enhance man's awareness of the necessity to respect the harmony and beauty of nature, thereby securing the fulfillment of the Divine promise that he or she shares with the entirety of the physical Universe.

Although the above paragraph conveys the essence of the advantages of addressing ecological issues from the viewpoint of evolutionary theology, there remains the following question: why this particular theological paradigm has enabled a better understanding of ecological issues? Following on from the conciliar constitution Dei Verbum, the 'deposit of faith' conveyed to the Apostles gradually reveals itself as our insight into the Divine mysteries deepens: the truths entrusted to the apostles can be expressed by gradually improving conceptual frameworks, thus allowing for a greater penetration into the Book of Nature. ${ }^{36}$ Since the depth of this penetration effected by contemporary sciences significantly surpasses our previous understanding of nature, a theology based on the conceptual foundation of such sciences deserves to be termed par excellance the continuation of the doctrinal tradition developed with the use of pre-scientific conceptual tools. What is most

35 M. Heller, Filozofia przypadku, Copernicus Center Press, Kraków 2012, 276.

36 W.P. Grygiel, In What Sense Can the Scientifically Driven Theology Be Considered as the Continuation of the Doctrinal Tradition?, Theological Research 6(2018), 31-52. 
important, however, is that this continuity is not devoid of methodological principles. Rather, its soundness is grounded in the rationality of the Universe as the expression of the immanence of the Logos.

\section{BIBLIOGRAPHY}

Ayala F.J., Darwin's Gift to Science and Religion, Joseph Henry Press, Washington 2007.

Benedict XVI, Address to the Diplomatic Corps Accredited to the Holy See (8 January 2007): AAS 2007, Vol. 99, 73.

de Chardin T., The Phenomenon of Man, William Collins, London 1959.

Edwards D., The God of Evolution: A Trinitarian Theology, Paulist Press, New York 1999.

Einstein A., The World As I See It, Forum and Century 84(1931), 193-194.

Francis, Encyclical Laudato si', Vatican City State 2015.

Grygiel W.P., Evolutionary Theology: A New Chapter in the Relations between Theology and Science, Studia Philosophiae Christianae 56(2020)3, 101-123.

Grygiel W.P., In What Sense Can the Scientifically Driven Theology Be Considered as the Continuation of the Doctrinal Tradition?, Theological Research 6(2018), 31-52.

Haught J., God After Darwin: A Theology of Evolution, Westview Press, Boulder 2008.

Haught J., Is Nature Enough?: Meaning and Truth in the Age of Science, Cambridge University Press, Cambridge 2006.

Haught J., Making Sense of Evolution: Darwin, God and the Drama of Life, Westminster John Knox Press 2010.

Haught J., Resting on the Future: Catholic Theology for an Unfinished Universe, Bloomsbury, New York - London - Oxford - New Delhi - Sydney 2015.

Haught J., The New Cosmic Story: Inside Our Awakening Universe, Yale University Press, New Haven - London 2017.

Heller M., Filozofia przypadku, Copernicus Center Press, Kraków 2012.

Heller M., Naukowy obraz świata a zadanie teologa, in: Obrazy świata w teologii $i$ w naukach przyrodniczych, eds. M. Heller, S. Budzik, S. Wszołek, Biblos, Tarnów 1996, 13-27.

Heller M., Sens życia i sens Wszechświata, Biblos, Tarnów 2002.

John Paul II, Catechesis (17 January 2001), Insegnamenti 41(2001), 179.

John XXIII, Encyclical Pacem in Terris, Vatican City State 1963. 
Liana Z., Teologia a naukowe obrazy świata, in: Wiara i nauka, ed. J. Mączka, Wydawnictwo Uniwersytetu Jagiellońskiego, Kraków 2010, 69-90.

Passmore J., Man's Responsibility for Nature, Scribner, New York 1974.

Paul VI, Apostolic Letter Octogesima Adveniens, Vatican City State 1971.

Peacocke A., Theology for a Scientific Age, Fortress Press, Minneapolis 1993.

Pedersen O., The Two Books: Historical Notes on Some Interactions Between Natural Science and Theology, Vatican Observatory Foundation, Vatican City State 2007. Rahner K., Anthropologie (theologische), in: Lexikon für Theologie und Kirche, eds. J. Höfer, K. Rahner, Freiburg/Br. 1957-67, col. 618-627.

Rahner K., Christology Within an Evolutionary World, in: K. Rahner, Theological Investigations V, Helicon Press, Baltimore 1966, 157-192.

St. Augustine, De Genesi ad litteram I, ed. J. Zecha, Bibliopola Academiae Litterarum Caesareae, Vienna 1894.

St. Basil, De legendis gentilium libris, ed. F. Boulenger, Paris 1935.

St. Thomas Aquinas, Summa Contra Gentiles III and IV (Latin-English Opera Omnia), ed. The Aquinas Institute, Emmaus Academic 2019.

Turek J., Filozoficzno-swiatopoglądowe implikacje dynamicznego obrazu wszechświata, in: Obrazy swiata w teologii i w naukach przyrodniczych, eds. M. Heller, S. Budzik, S. Wszołek, Biblos, Tarnów 1996, 125-145.

Vaticanum II, Dei Verbum, in: Vatican Council II, The Conciliar and Post Conciliar Documents, ed. A. Flannery, Costello Publishing Company, Northport - New York 1980, 750-765.

Wojciech P. Grygiel

Uniwersytet Papieski Jana Pawła II w Krakowie, Wydział Filozoficzny

(The Pontifical University of John Paul II in Krakow, Faculty of Philosophy, Poland)

Centrum Kopernika Badań Interdyscyplinarnych Uniwersytetu Jagiellońskiego, Kraków

(Copernicus Center for Interdisciplinary Studies of the Jagiellonian University, Cracow, Poland)

ORCID: https://orcid.org/0000-0003-2599-0410

wojciech.grygiel@upjp2.edu.pl

DOI: $10.21697 /$ spch.2020.56.4.13 